ISSN 0258-7122

Bangladesh J. Agril. Res. 33(3) : 549-554, December 2008

\title{
EFFECT OF RHIZOBIUM INOCULATION ON NODULATION AND YIELD OF CHICKPEA IN CALCAREOUS SOIL
}

\author{
M.A.H. BHUIYAN ${ }^{1}$, D. KHANAM ${ }^{2}$, M.F. HOSSAIN ${ }^{3}$ AND M.S. AHMED ${ }^{4}$
}

\begin{abstract}
Two field experiments were carried out during two consecutive rabi seasons of 2002-03 and 2003-2004 at Farming System Research Site, Chabbish Nagar, Rajshahi (AEZ 11) with a view to assessing the effect of Rhizobium inoculation on four varieties of chickpea viz., BARI Chola-3, BARI Chola-4, BARI Chola-5 and BART Chola-6. Each variety was tested with and without Rhizobium inoculation. Each plot received basal application of $22 \mathrm{~kg}$ P/ha as TSP, $42 \mathrm{~kg} \mathrm{K/ha}$ as MOP, $20 \mathrm{~kg} \mathrm{~S} / \mathrm{ha}$ as gypsum and $5 \mathrm{~kg} \mathrm{Zn/ha} \mathrm{as} \mathrm{zinc} \mathrm{oxide.}$ Peat based rhizohial inoculurn (Rhizohium strain RCa-220) @ 1.5 kg/ha was used for seed inoculation. Inoculated plants gave significantly higher nodule number, nodule weight, stover yield and seed yield compared to uninoculated plants. Among four varieties, BARI Chola-3 produced the highest nodule number, nodule weight and stover yield, while the highest yield was obtained from BARI Chola-4.
\end{abstract}

Key Words: Chickpea, Rhizobium, nodulation, yield.

\section{Introduction}

Chickpea (Cicer arietinum L.) is a major pulse crop in Bangladesh. It stands 5th in respect of area (13915 ha) and production (10380 tons), and 2nd in consumption priority (BBS, 2004). The average yield of chickpea is low (746 $\mathrm{kg} / \mathrm{ha}$ ) which can be attributed to lack of high yielding varieties and suitable rhizobial strains capable of fixing high atmospheric nitrogen. The soils of Bangladesh, especially Rajshahi regions are deficient in nitrogen fixing bacteria (Rhizohium spp.) which causes poor yield of chickpea (Bhuiyan et al., 1998; Khanam et al., 1999). The Bangladesh Agricultural Research Institute (BARI) has developed a good number of varieties of chickpea. There is a good possibility to increase its production by exploiting better colonization of the roots and rhizospheres through application of effective nitrogen fixing bacteria to the seed or to the soil. This can minimize uses of nitrogenous fertilizer, which is very costly in this country. Using high yielding varieties of chickpea along with use of effective rhizohial strains can enhance the yield. The present investigation was undertaken to study the response of different chickpea genotypes to Rhizobium inoculation in High Ganges River Floodplain (AEZ 11) soil of Bangladesh.

\footnotetext{
1،Senior Scientific Officer, Soil Microbiology Laboratory, BARI, Gazipur, ${ }^{2}$ Principal Scientific Officer, Soil Microbiology Laboratory, BARI, Gazipur, ${ }^{3}$ Scientific Officer, OnFarm Research Division, BARI, Barind, Rajshahi, ${ }^{4}$ Scientific Officer, On-Farm Research Division, BARI, Faridpur, Bangladesh.
} 


\section{Materials and Method}

Two field experiments with chickpea were carried out during rabi seasons of 2002-03 and 2003-04 at Farming System Research Site, Chabbish Nagar,Rajshahi of On-farm Research Division, Bangladesh Agricultural Research Institute. The site belongs to the Agro-ecological Zone 11 (High Ganges River Floodplain). The treatments were designed in Randomized Complete Block having 4 replications for each treatment. The unit plot size was $4 \mathrm{~m} \times 3 \mathrm{~m}$. Four varieties of chickpea, namely BARI Chola-3, BARI Chola-4, BARI Chola-5 and BARI Chola-6 were tested with and without Rhizobium inoculation. Basal application was made with $\mathrm{P}_{22} \mathrm{~K}_{42} \mathrm{~S}_{20} \mathrm{Zn}_{5} \mathrm{~kg}$ /ha with no $\mathrm{N}$ application. Peat based rhizobial inoculum $1.5 \mathrm{~kg} / \mathrm{ha}$ was used for inoculation treatment. The Rhizobjum strain was BARI RCa-220 and the number of Rhizohium cells/g inoculant was 2.4 x 108. Before application of fertilizers, composite soil samples were collected from 0 to $15 \mathrm{~cm}$ depth and analyzed for chemical properties (Table 1). The seeds were coated with Rhizobium inoculum before sowing and sowing was made 25 November 2002 and 16 November 2003. Row to row distance was $30 \mathrm{~cm}$ and plant to plant was $15 \mathrm{~cm}$. Thinning, weeding and other intercultural operations were done as and when necessary. Ten randomly selected plants were uprooted at $50 \%$ flowering stage from each plot to record nodule weight and nodule number. Crops were harvested on 01 April 2003 and 21 March 2004. Stover and seed yields for each unit plot were recorded. Data on 1000-seed weight was also taken. All data were analyzed statistically.

Table 1. Nutrient status and rhizobial population of the initial soil sample $(0-15 \mathrm{~cm}$ depth).

\begin{tabular}{|c|c|c|c|c|c|c|c|c|c|}
\hline \multirow{2}{*}{ Year } & \multirow{2}{*}{$\mathrm{pH}$} & \multirow{2}{*}{$\begin{array}{c}\text { Organic } \\
\text { matter } \\
(\%)\end{array}$} & $\mathrm{Ca}$ & $\mathrm{Mg}$ & $\mathrm{K}$ & $\mathrm{NH}_{4}-\mathrm{N}$ & $\mathrm{P}$ & $\mathrm{S}$ & \multirow{2}{*}{$\begin{array}{c}\text { Rhizobial } \\
\text { population/g } \\
\text { soil }\end{array}$} \\
\hline & & & \multicolumn{3}{|c|}{ (meq/100g) } & \multicolumn{3}{|c|}{$(\mu \mathrm{g} / \mathrm{g}$} & \\
\hline $2002-03$ & 7.1 & 0.45 & 16.3 & 4.21 & 0.22 & 32 & 39 & 20 & $2.1 \times 10^{1}$ \\
\hline 2003-04 & 6.6 & 0.55 & 19.1 & 5.57 & 0.21 & 29 & 32 & 19 & $3.2 \times 101$ \\
\hline \multicolumn{3}{|c|}{ Critical level } & 2.0 & 0.8 & 0.20 & 75 & 14 & 12 & - \\
\hline
\end{tabular}

\section{Results and Discussion}

Effects of varieties on nodule number, nodule weight, 1000-seed weight, stover yield and seed yield have been presented in Table 2. Among the varieties studied, BARI Chola-3 gave significantly higher nodule number, nodule weight and stover yield. BARI Chola-6 produced higher 1000-seed weight in 2002-03. The highest seed yield was recorded in BARI Chola-4, which was significantly higher 
than other varieties in 2002-03 but identical to all other varieties in 2003-04. Khanam et al. (1994) in Bangladesh and Gupta and Namdeo (1986a) have also reported varied in nodulation and yield of chickpea due to use of different varieties. In the present experiment, BARI Chola-3 produced the highest nodule number and nodule weight, while BARI Chola- 4 gave the highest seed yields which were significantly higher over all other varieties in 2002-03, but identical to other varieties in 2003-04. In another study, Eusuf Zai el al. (1999) found significantly more nodules in variety BARI Chola-6.

Table 2. Effects of different varieties on nodulation and yield of chickpea.

\begin{tabular}{l|c|l|l|l|l}
\hline \multicolumn{1}{c|}{ Variety } & $\begin{array}{c}\text { Nodules } \\
\text { /plant }\end{array}$ & $\begin{array}{c}\text { Nodule wt } \\
\text { (mg/plant) }\end{array}$ & $\begin{array}{c}1000 \text {-seed } \\
\text { wt }(\mathrm{g})\end{array}$ & $\begin{array}{c}\text { Stover yield } \\
\text { (t/ha) }\end{array}$ & $\begin{array}{c}\text { Seed yield } \\
(\mathrm{t} / \mathrm{ha})\end{array}$ \\
\hline$\underline{2002-03}$ & & & & \\
BARICho1a-3 & $42.6 \mathrm{a}$ & $288 \mathrm{a}$ & $138 \mathrm{a}$ & $2.42 \mathrm{a}$ & $1.08 \mathrm{c}$ \\
BARICho1a-4 & $24.4 \mathrm{c}$ & $144 \mathrm{c}$ & $122 \mathrm{~b}$ & $2.15 \mathrm{~b}$ & $1.35 \mathrm{a}$ \\
BARI Chola-5 & $24.6 \mathrm{c}$ & $172 \mathrm{~b}$ & $113 \mathrm{c}$ & $2.34 \mathrm{a}$ & $1.23 \mathrm{~b}$ \\
BARI Chola-6 & $30.3 \mathrm{~b}$ & $186 \mathrm{~b}$ & $144 \mathrm{a}$ & $2.17 \mathrm{~b}$ & $1.11 \mathrm{c}$ \\
\hline SE \pm & 2.43 & 10.0 & 2.82 & 0.07 & 0.05 \\
\hline 2003-04 & & & & & \\
BARICho1a-3 & $46.9 \mathrm{a}$ & $239 \mathrm{a}$ & $162 \mathrm{a}$ & $2.01 \mathrm{a}$ & 1.27 \\
BART Chola-4 & $36.4 \mathrm{~b}$ & $169 \mathrm{c}$ & $143 \mathrm{~b}$ & $1.84 \mathrm{~b}$ & 1.29 \\
BARIChoIa-5 & $31.4 \mathrm{c}$ & $175 \mathrm{bc}$ & $134 \mathrm{c}$ & $1.57 \mathrm{c}$ & 1.12 \\
BARICho1a-6 & $43.0 \mathrm{a}$ & $192 \mathrm{~b}$ & $160 \mathrm{a}$ & $1.84 \mathrm{~b}$ & 1.19 \\
\hline SE( \pm ) & 1.44 & 7.2 & 2.12 & 0.05 & $\mathrm{NS}$ \\
\hline
\end{tabular}

Means followed by different letters are significantly different at $5 \%$ level by DMRT

NS: Not significant

Effects of rhizobial inoculation on nodule number, nodule weight, 1000-seed weight, stover yield and seed yield have been presented in Table 3. Inoculated plants gave significantly higher nodule number, nodule weight, stover yield and seed yield compared to uninoculated control. Khanam et al. (1994) reported that inoculation with Rhizobium strains gave higher nodule number, nodule dry weight, stover yield and seed yield compared to uninoculated plants. Bhuiyan et al. (1998) found that Rhizobium inoculation increased nodulation and seed yields upto 35\%. Gupta and Namdeo (1996b) found that seed inoculation with Rhizohizim increased chickpea seed yields by $9.6-27.9 \%$. 
Table 3. Effects of rhizobial inoculant on nodulation and yield of chickpea.

\begin{tabular}{l|c|c|c|c|c}
\hline \multicolumn{1}{c|}{ Inoculants } & $\begin{array}{c}\text { Nodules } \\
\text { /plant }\end{array}$ & $\begin{array}{c}\text { Nodule wt } \\
\text { (mg/plant) }\end{array}$ & $\begin{array}{c}100 \text {-seed } \\
\text { wt }(\mathrm{g})\end{array}$ & $\begin{array}{c}\text { Stover yield } \\
(\mathrm{t} / \mathrm{ha})\end{array}$ & $\begin{array}{c}\text { Seed yield } \\
(\mathrm{t} / \mathrm{ha})\end{array}$ \\
\hline$\underline{2002-03}$ & & & & & \\
Uninoculated & $25.8 \mathrm{~b}$ & $167 \mathrm{~b}$ & 129 & $2.06 \mathrm{~b}$ & $1.09 \mathrm{~b}$ \\
Inoculated & $35.2 \mathrm{a}$ & $229 \mathrm{a}$ & 129 & $2.48 \mathrm{a}$ & $1.29 \mathrm{a}$ \\
\hline $\mathrm{SE}( \pm)$ & 1.72 & 7.1 & $\mathrm{NS}$ & 0.05 & 0.04 \\
\hline 2003-04 & & & & & \\
Uninoculated & $32.1 \mathrm{~b}$ & $176 \mathrm{~b}$ & $147 \mathrm{~b}$ & $1.73 \mathrm{~b}$ & $1.15 \mathrm{~b}$ \\
Inoculated & $46.8 \mathrm{a}$ & $212 \mathrm{a}$ & $153 \mathrm{a}$ & $1.90 \mathrm{a}$ & $1.29 \mathrm{a}$ \\
\hline $\mathrm{SE}( \pm)$ & 1.02 & 5.08 & 1.50 & 0.04 & 0.04 \\
\hline
\end{tabular}

Means followed by different letters are significantly different at 5\% level by DMRT NS: Not significant

Interaction effects of varieties and rhizobial inoculation on nodule number, nodule weight, 1000-seed weight, stover yield and seed yield have been presented in Table 4 . The highest nodule number, nodule weight and stover yield were recorded with BARI Chola-3 with inoculation, but the highest seed yield was observed in inoculated BARI Chola-4 (16.0\% higher in 2002-03 and 11.6\% higher in 2003-04 over uninoculated control). Response to Rhizohium inoculation was more pronounced in BARI Chola-5 which was $21.6 \%$ higher over uninoculated control in 2002-03 and 11.7\% higher in 2003-04.

Positive and significant correlations of nodule number were observed with nodule weight. and 1000-seed weight and stover yield in both years. On the contrary, there was no significant correlation between seed yield and nodule number or weight.

The nitrogen content of soil was below critical level in both the years (Table 1). Hence, inoculation with Rhizobium strains no. RCa-220 gave higher nodule number and weight in BARI Chola-3, but higher seed yields in BARI Chola-4 variety. Again, the seed yield varied significantly with the varieties in 2002-03 showing the highest result recorded by BARI Chola-4 and the lowest by BARI Chola-3. No significant difference was observed between varieties in 2003-04. 
Table 4. Interaction effects of varieties and rhizobial inoculant on nodulation and yield of chickpea.

\begin{tabular}{l|c|l|l|l|l}
\hline \multicolumn{1}{c|}{ Treatment } & $\begin{array}{c}\text { Nodules } \\
\text { /plant }\end{array}$ & $\begin{array}{c}\text { Nodule } \\
\text { wt } \\
\text { (mg/plant) }\end{array}$ & $\begin{array}{c}\text { 1000-seed } \\
\text { wt (g) }\end{array}$ & $\begin{array}{c}\text { Stover yield } \\
\text { (t/ha) }\end{array}$ & $\begin{array}{c}\text { Seed yield } \\
(1 / \text { ha })\end{array}$ \\
\hline 2002-03 & & & & \\
BARI Chola-3xU & 35.2 & 260 & 138 & 2.17 & 0.98 \\
BARIChoIa-3x1 & 50.0 & 316 & 138 & 2.66 & 1.17 \\
BARICho1a-4xU & 22.8 & 126 & 122 & 1.94 & 1.25 \\
BARI Chola-4x1 & 26.0 & 162 & 122 & 2.36 & 1.45 \\
BARI Chola-5xU & 20.6 & 132 & 111 & 2.14 & 1.11 \\
BARICho1a-5x1 & 28.6 & 212 & 116 & 2.54 & 1.35 \\
BARI Chola-6xU & 24.4 & 148 & 148 & 2.00 & 1.03 \\
BARI Chola-6x1 & 36.2 & 224 & 140 & 2.34 & 1.19 \\
\hline SE( \pm ) & $\mathrm{ns}$ & $\mathrm{ns}$ & $\mathrm{ns}$ & $\mathrm{ns}$ & $\mathrm{ns}$ \\
CV (\%) & 15.9 & 10.2 & 4.4 & 6.3 & 8.7 \\
\hline 2003-04 & & & & & \\
BARI Chola-3xU & 36.8 & 217 & 158 & 1.97 & 1.23 \\
BARI Chola-3x1 & 57.0 & 261 & 166 & 2.05 & 1.31 \\
BARI Chola-4xU & 29.3 & 150 & 141 & 1.67 & 1.20 \\
BARICho1a-4x1 & 43.5 & 188 & 146 & 2,00 & 1.39 \\
BARI Chola-5xU & 27.3 & 158 & 129 & 1.51 & 1.03 \\
BARIChola-5x1 & 35.5 & 193 & 139 & 1.63 & 1.21 \\
BARI Chola-6xU & 35.0 & 179 & 159 & 1.75 & 1.14 \\
BARI Chola-6x1 & 51.0 & 204 & 160 & 1.93 & 1.26 \\
\hline SE( \pm ) & $\mathrm{ns}$ & $\mathrm{ns}$ & $\mathrm{ns}$ & $\mathrm{ns}$ & $\mathrm{ns}$ \\
CV (\%) & 10.4 & 10.5 & 4.0 & 8.2 & 12.8 \\
\hline U- & & & &
\end{tabular}

$\mathrm{U}=$ Uninoculated, I= Inoculated, NS= Not significant

\section{References}

BBS. 2004. Year Book of Agril. Statistics of Bangladesh. Bangladesh Bureau of Statistics. Ministry of Planning, Govt. of the People's Republic of Bangladesh, Dhaka. p. 63.

Bhuiyan, M.A.H., D. Khanam, M. R. Khatun and M.S. Hassan. 1998. Effect of molybdenum, boron and Rhizobium on nodulation, growth and yield of chickpea. Bull. Inst. Trop. Agric., Kyushu Univ. 21: 1-7 
Eusuf Zai, A.K., A.R.M. Solaiman and J.U. Ahmed. 1999. Response of some chickpea varieties to Rhizobium inoculation in respect to nodulation, biological nitrogen fixation and dry matter yield. Bangladesh J. Microbiol. 16(2): 135-144.

Gupta, S.C. and S.L. Namdeo. 1996a. Effect of Rhizobium inoculation on symbiotic traits, grain yield and quality of chickpea genotypes under rainfed conditions. Crop Res. Hissar. 12(2): 127-132.

Gupta, S.C. and S.L. Namdeo. 1996b. Effect of Rhizobium strains on symbiotic traits and grain yield of chickpea. Indian J. Pulses Res. 9(1): 94-95.

Khanam, D., M. H. H. Rahman, D. Begum, M.A. Haque and A.K.M. Hossain. 1994. Inoculation and varietal intractions of chickpea (Cicer arietinum L.) in Bangladesh. Thai .\& Agric. Sci. 27: 123-130.

Khanam, D., M.A.H. Bhuiyan, M.H.H. Rahman and A.K.M. Hossain. 1999. On-farm experience of the application and adoption of biological nitrogen fixation technology in Bangladesh. Bangladesh J. Agril. Res. 24(2): 375-382. 